\title{
Endocrine Adaptation to Malnutrition
}

\author{
JO ANNE BRASEL ${ }^{(56)}$ \\ College of Physicians and Surgeons, Columbia University, New York, New York, USA
}

Good morning, everyone. I want to welcome you all to the third of the Special Symposia sponsored by the APS and SPR in celebration of the International Year of the Child. The NICHD has provided appreciated assistance for these sessions. The SPR is also particularly grateful to the Journal of Pediatrics Educational Program for its loyal annual support of the SPR plenary sessions for many years, including 1979 . I am undoubtedly prejudiced, but I think the program this morning will be a particularly exciting one. The ability to adjust and to adapt and remarkable powers of recovery and catch-up are hallmarks of our pediatric patients in distinct contrast to those of our internal medicine colleagues. Obviously, I can only speak for myself, but these were important factors in my own choice of pediatrics. I was also fortunate as a medical student to have two splendid, gifted, and compassionate role models in Henry Kempe and Henry Silver. New developments in our knowledge of the process of fetal sexual differentiation, the remarkable events which accompany pregnancy, recent insights into the geography of the chromosomes which may lead to an understanding eventually of the regulation of DNA transcription, the ultimate site of control of differentiation, and exciting information on the nature of cell receptors and their role in the fine tuning of intracellular metabolism will be presented this morning by experts in their fields. I join you in anticipation of their presentation.

I will discuss the endocrine changes in malnutrition which involve two specific areas of my own interest. I propose for your consideration the hypothesis that certain changes which are considered abnormalities, as evidenced by the way we often present and discuss the laboratory results, are actually appropriate physiologic adaptations to stress. In the specific instance of malnutrition, a case can be made that many of the endocrine alterations are in response to the decreased availability of energy substrates and amino acids occurring secondary to decreased or imbalanced nutrient intake. The data I will report come primarily from more recent studies in children in developing countries and will be arbitrarily limited to those hormones which are important in energy homeostasis.

In Figure 1, fasting levels of growth hormone in untreated and treated children with kwashiorkor and in control subjects from the work of Pimstone et al. from South Africa are shown. There is no disagreement among the various investigators $(16,30,32-35,40$, 48) that basal growth hormone levels are elevated in untreated subjects with kwashiorkor and that they return to control levels with dietary treatment. In addition, most observers agree that growth hormone is also elevated in marasmus. A few exceptions have been reported where growth hormone levels were normal or diminished $(26,43)$; this may relate to differences in the patient populations investigated or in the conditions under which they were studied.

As seen in Figure 2, in the face of elevated growth hormone in kwashiorkor patients, bioassayable somatomedin is reduced (15, 35). The somatomedins are growth hormone-dependent peripheral effectors of many of the anabolic actions of growth hormone, especially those causing skeletal growth. As the elevated growth hormone levels fall and albumin and transferrin levels rise with treatment, somatomedin increases to normal values. This inverse relationship between growth hormone and somatomedin is unex- pected because their levels ordinarily move in concert. Some observers suggested that a somatomedin inhibitor might be present. However, more recent preliminary work by Van Wyk (53) on serum samples from Pimstone's patients suggests that absolute somatomedin $C$ levels, measured by either a specific radioimmunoassay or a receptor assay, are truly reduced and that growth hormone levels begin to fall toward normal before somatomedin $\mathrm{C}$ begins to rise.

Another abnormality noted in kwashiorkor is that growth hormone is not suppressible by glucose infusion or by an albumin infusion to bring plasma protein levels to within normal limits acutely $(15,16,32-36,48)$. As shown in Figure 3 , it is also unsuppressible by a high carbohydrate diet over a 3-day period. However, with a protein-containing diet for as short a period as 3 days, the growth hormone levels begin to fall significantly, but it requires some 2 to $4 \mathrm{wk}$ of appropriate dietary therapy before levels decline to control values (33-35). The fact that prolonged protein ingestion is required to decrease the growth hormone and elevate the somatomedin suggests that the site of control resides elsewhere than in absolute plasma amino acid and/or protein concentrations. This lack of suppressibility after carbohydrate is similar to the situation in acromegaly. Also, analogous to findings in acromegaly, patients with protein-calorie malnutrition may overrespond to stimuli used to provoke the release of growth hormone, such as arginine infusion $(30,48)$. After refeeding, the response to arginine returns to normal. Although the precise mechanism for the elevation of growth hormone is unknown, recent evidence (15) suggests that it is not due to a prolonged halflife or delayed metabolic clearance in malnourished subjects.

Protein-calorie malnutrition also affects insulin levels $(2-4,6$, $14,16,21,22,25,30-32,39,43,46)$. Undernutrition is characterized by a failure to respond normally to both low and high blood sugar levels. Both glucose intolerance, i.e., a diabetic-like curve, and a flat glucose tolerance curve can be seen. Hypoinsulinemia, especially after insulinogenic stimuli, and increased sensitivity to exogenous insulin can also be noted. In Figure 4, the studies of Milner (25) of the responses to an IV glucose load are shown. Glucose levels are consistently higher in the malnourished groups; the insulin response before treatment is very sluggish, consistent with the diminished glucose clearance. The response becomes quite brisk after nutritional therapy. Such findings can also be seen in growth hormone deficiency, but as noted above and as seen in Figure 4, growth hormone is actually elevated in malnutrition.

Becker et al. (3) have shown that the degree of insulinopenia following an IV glucose load is proportional to the severity of the malnutrition, to the levels of serum albumin and alanine on admission, and to the extent of the glucose intolerance. Basal insulin levels are inversely proportional to basal growth hormone levels. In addition, the rise with therapy in insulin correlates directly with the return to normal of albumin levels. In some cases, the insulin response to insulinogenic stimuli may not only be blunted, as mentioned above, but may also reach the peak value later than in control subjects $(6,30,39)$; this type of response has also been noted after total starvation or during restricted carbohydrate intake in adults $(17,51)$. The precise mechanisms for the defects in insulin secretion are unknown, but body potas- 


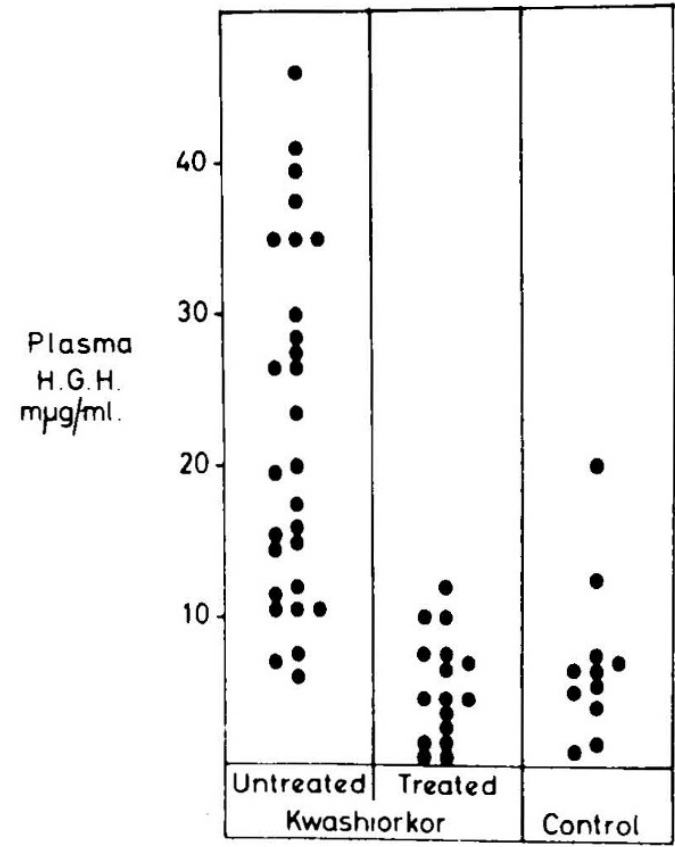

Fig. 1. Plasma growth hormone levels in children with kwashiorkor before and after nutritional rehabilitation and in normal control children. Reprinted with permission from B. L. Pimstone et al., Lancet, 2: 779-780 (1966).
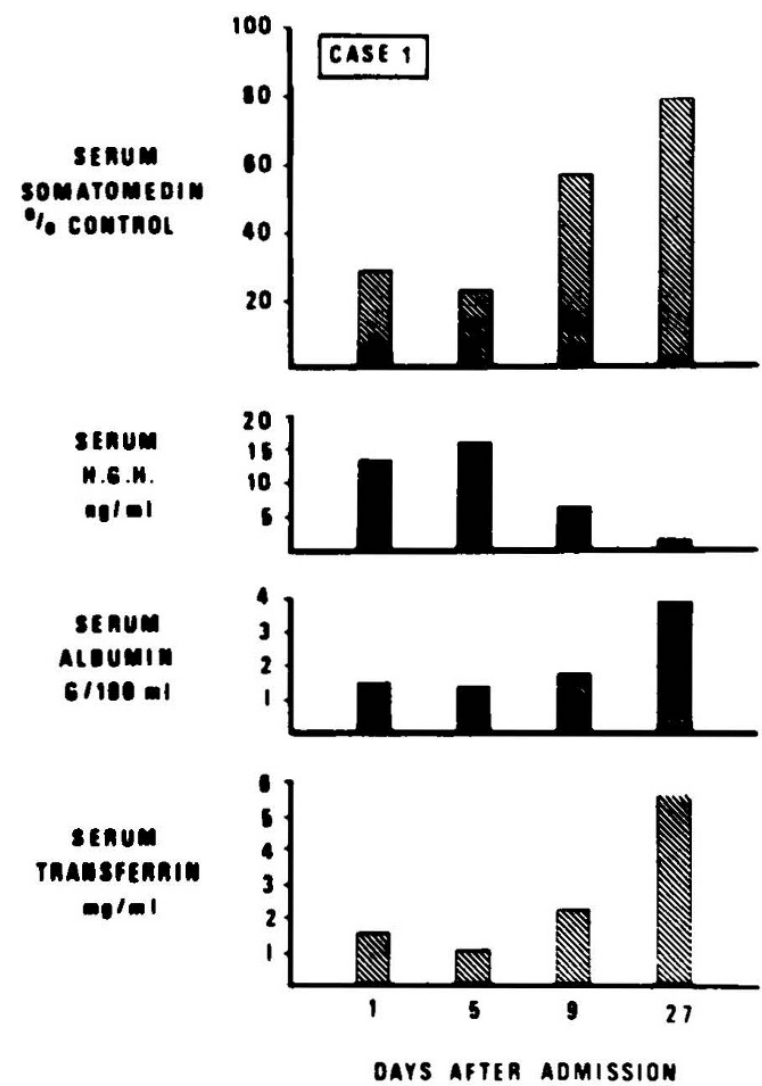

Fig. 2. Somatomedin, growth hormone, albumin, and transferrin levels in a child with kwashiorkor during the course of nutritional rehabilitation. Reprinted with permission from B. L. Pimstone et al.: In: L. I. Gardner and P. Amacher: Endocrine Aspects of Malnutrition (The Kroc Foundation, Santa Ynez, CA, 1973).

sium and/or chromium deficits, decreased gastrointestinal absorption, defective gut insulinotropic factors, and disordered insulin transport by the pancreas have all been mentioned and are supported by several studies $(18,39)$. However, actual pancreatic damage or decreased functional pancreatic mass has not been ruled out. All these abnormalities return to normal with treatment, but in some cases complete recovery may not occur for months (39).

Data on glucagon secretion in malnutrition are scanty, and to my knowledge, none are available in young subjects. Studies of short-term starvation in obese adults (27) reveal a peak increase in levels in the first few days when gluconeogenesis is maximal. As fatty acids and ketones become the major fuel sources with more prolonged starvation, glucagon falls toward baseline levels. Earlier work (21) shows similar glucagon responses to fasting for periods up to $6 \mathrm{wk}$. The data of Aguilar-Parada et al. (1) also emphasize the early and transient nature of the glucagon response to starvation. None of this work, however, reports levels of glucagon after chronic undernutrition, so it is not known if the responses to short-term fasting and chronic undernutrition are similar.

The earlier studies of adrenal function which relied on the urinary excretion of glucocorticoid metabolites, the 17-hydroxycorticosteroids, led to the belief that hypoadrenalism accompanied chronic malnutrition. Two recent investigations, utilizing newer methodologies, reveal that the hypothalamic-pituitary-adrenal axis is not only intact and responds appropriately to various types of stimulation, including stress, but also may be in a state of slight hyperfunction. The first study (47) was of 10 adults with chronic protein calorie malnutrition associated with edema and hypoalbuminemia. Both plasma total cortisol and plasma free cortisol, the metabolically active form, were increased; however, the total 17-hydroxycorticosteroid excretion was diminished, although the urinary total free cortisol was normal. Plasma cortisol metabolic clearance and production rate were decreased. Adrenal responsiveness to exogenous ACTH or metapyrone was normal, but

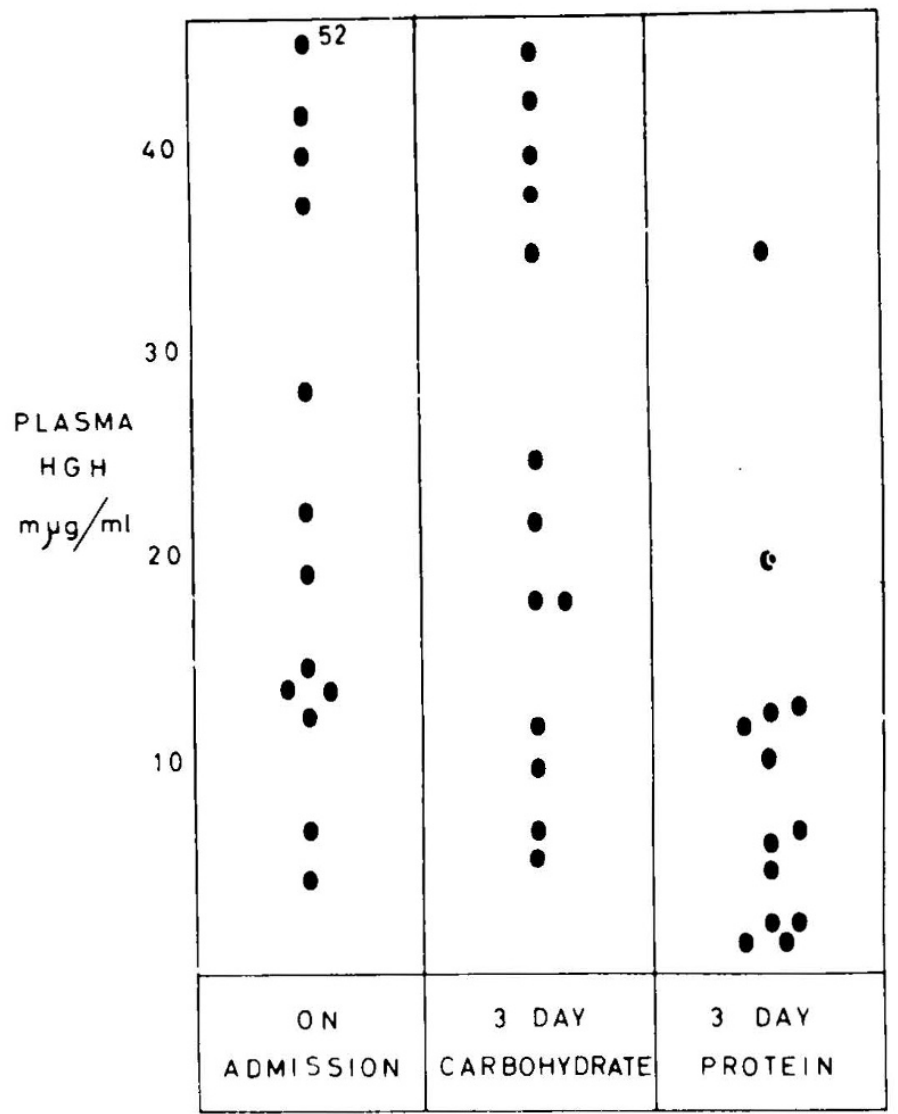

Fig. 3. Plasma growth hormone in children with protein-calorie malnutrition on admission and after 3 days on either a high carbohydrate, protein-free diet, or a protein-containing diet. Reprinted with permission from B. L. Pimstone et al., American Journal of Clinical Nutrition, 21: 482487 (1968). 

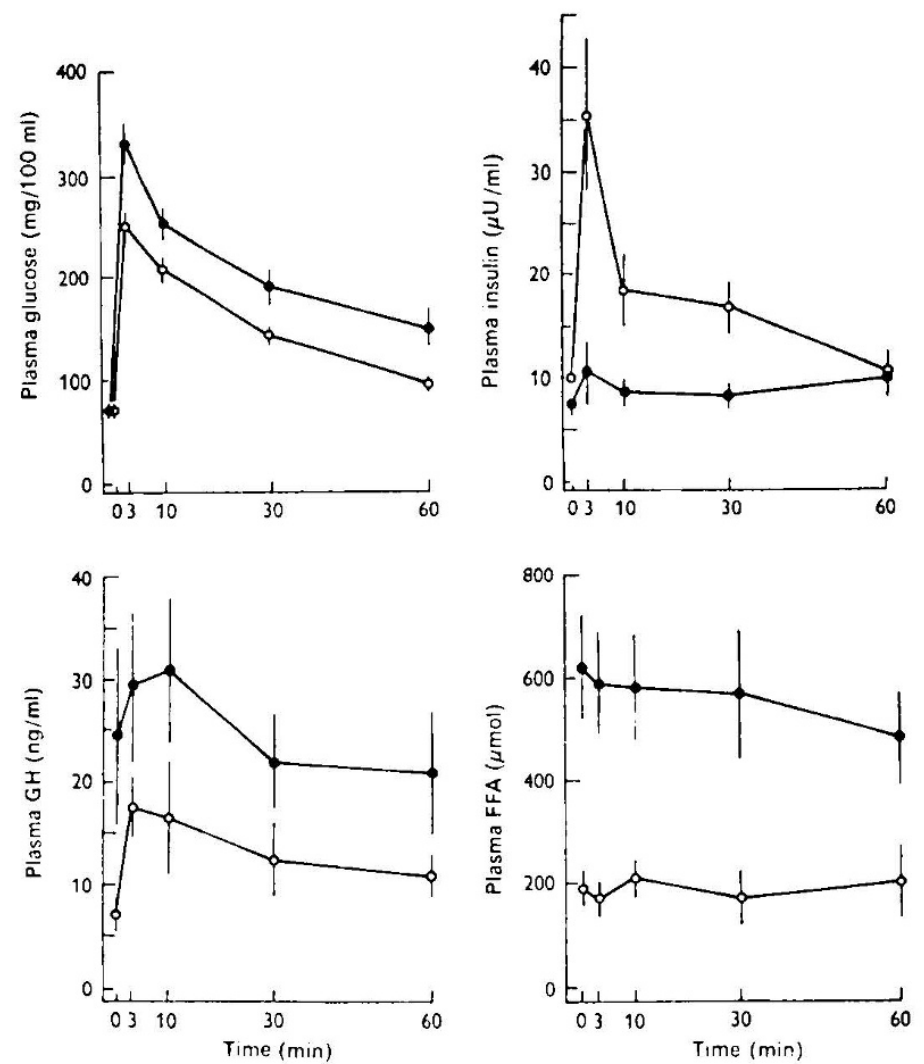

Fig. 4. Plasma glucose, insulin, growth hormone, and free fatty acids after an IV glucose tolerance test. $\boldsymbol{Q}$, values in untreated malnourished subjects, $O$, values obtained after recovery. Reprinted with permission from R. D. G. Milner, Proceedings of the Nutrition Society, 31: 219-223 (1972).

exogenous decadron failed to produce the expected degree of suppression of cortisol production. The authors concluded that the pituitary-adrenal axis was intact, but that ACTH secretion was autonomously controlled by an unknown factor(s), perhaps the chronic stress of the malnutrition, and failed to show the expected reduction in the face of either increased endogenous or exogenous glucocorticoids. The second study (44) was undertaken in 35 malnourished children; the results are similar. Plasma-free cortisol levels were increased and rose promptly in the presence of acute infection. Additionally, corticosteroid-binding globulin was diminished, even in those subjects without edema. In both studies, dietary therapy was followed by a return toward normal of all abnormalities which began within a short time of refeeding.

There is probably more confusion about the functional status of the thyroid than any of the endocrine systems studied in patients with malnutrition. Investigators have variously concluded that hypothyroidism, euthyroidism, or hyperthyroidism exists. Some of the confusion is slowly being clarified by recent, sophisticated techniques for evaluating thyroid hormone metabolism. Most of the studies concluding that hypothyroidism existed were based on the findings of low BMR values and decreased PBI or total thyroxine levels. There are other more obvious reasons for a diminished BMR in severely wasted patients than hypothyroidism. In patients in which plasma proteins are reduced, the thyroidbinding globulins may also decrease. Thus, the free or metabolically active form of the hormone may remain unchanged or may decrease or increase, but those alterations could be masked by changes in the binding globulins and hence in the PBI or total thyroxine $(7,20,28)$. Recent work has focused on the measurement of not only total thyroxine, but also free thyroxine, total triiodothyronine, and free triiodothyronine, the latter two probably being more important in the cellular actions of thyroid hormone. Additionally, reverse triiodothyronine, an alternate inactive metabolite of thyroxine, has been measured. In these studies, total and free thyroxine have been found to be normal, decreased, or increased; however, most studies are in agreement that total and free triiodothyronine are decreased $(7-9,19,28)$. Marked decreases in the triiodothyronine can occur within a few hr of total fasting in normal weight adults (24). Significant reductions in serum triiodothyronine concentration occur within $24 \mathrm{hr}$; after $60 \mathrm{hr}$ of fasting, the values have fallen to approximately $60 \%$ of control levels as shown in Figure 5. Other studies during complete fasting in adults $(10,41,49,52)$ similarly reveal significant decreases in serum triiodothyronine.

A growing consensus is emerging that either reduced deiodination of thyroxine to triiodothyronine or increased formation of the inactive form, reverse triiodothyronine, occurs $(8,9,13,24,41$, $49,52)$. The end result in either case would be decreased active hormone at the cellular level. The alterations in triiodothyronine and reverse triiodothyronine appear to depend in part on the degree of caloric deficit and on the presence or absence of carbohydrate in the diet (49). These two thyroxine metabolites do not always change in a precisely reciprocal fashion. The variable changes in thyroxine levels noted earlier could be explained by a block in its metabolism to triiodothyronine leading to an increased thyroxine level, by an excessive metabolism to reverse triiodothyronine leading to a decreased thyroxine level, or by some balance of the two processes leading to no change.

Measurements of thyroid-stimulating hormone, assuming an intact pituitary, might provide some clue as to whether primary hypothyroidism is actually present. However, results are also equivocal with normal, decreased, or increased levels being reported $(7,9,19,41)$. In a recent study by Croxson et al. (10), using sensitive radioimmunoassay techniques, serum TSH in two normal weight and six obese adult subjects fell significantly within 1 to 2 days of fasting. Despite continued fasting, levels gradually rose to return to baseline values by days 6 to 7 of the fast. The levels after 1 to 2 days of refeeding were not statistically different from those at the end of the fast. In another study (54), brief fasts of 12 to 36 $\mathrm{hr}$ in nine normal adult men led to diminished thyroid-stimulating hormone release after administration of synthetic thyrotropinreleasing hormone, suggesting inadequate pituitary reserve. In another (37), an exaggerated release of thyroid-stimulating hormone, after administration of releasing hormone, was seen in several children with elevated basal TSH levels in association with protein-calorie malnutrition; this response is reminiscent of that seen in subjects with primary hypothyroidism. In contrast, 4 wk of fasting in nine obese subjects (41) did not change basal serum TSH concentration or the TSH or triiodothyronine response to exogenous releasing hormone. Similarly, serum TSH concentra-

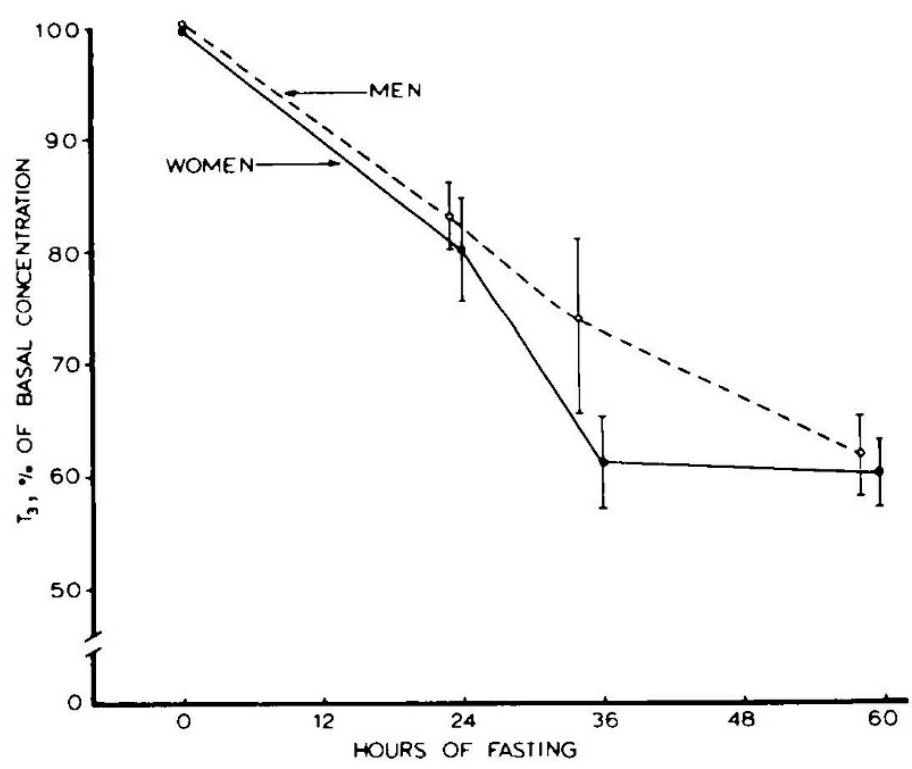

Fig. 5. Percent change in serum triiodothyronine during fasting. Reprinted with permission from T. J. Merimee and E. S. Fineberg: Metabolism, 25: 79-83 (1976). 
tion did not change following a 60 -hr fast in 14 normal weight adults (24).

One of the most intriguing developments in this field was a study of young adult female rats fasted for 5 days (45). As noted in the human investigations, serum triiodothyronine levels fell significantly. In addition, the triiodothyronine nuclear binding capacity of hepatic tissue was reduced. Inasmuch as thyroid hormone is felt to exert its biologic effects through the formation of a triiodothyronine-nuclear receptor complex, this decreased binding can be viewed as an additional, independent mechanism for decreasing the effective level of thyroid hormone. These abnormalities may not be due to a direct effect on nuclear binding per se because elevated plasma glucagon can temporarily decrease nuclear binding in the rat (11). In addition, prolonged glucagon elevation inhibits the expected response in malic enzyme activity even after nuclear binding has returned to control values (11). Thus, elevations of glucagon in times of energy substrate unavailability may play a role in determining the level of biologically active thyroid hormone independent of glandular hormonal secretion. Many questions regarding thyroid function in malnutrition remain unanswered, but taken on balance, the evidence seems to point more to some degree of hypothyroidism, at least at a cellular level.

Some discussion of catecholamines would be desirable in a review such as this because they can play an important role in fuel metabolism, especially in times of stress. However, data are very meager, are conflicting, and are based on imprecise measurement techniques. It appears the malnourished infant and child are able to mount a catecholamine response to stress, but it is not clear whether these compounds play a long-term role in the adaptation to chronic malnutrition (29).

How do these alterations in various hormonal levels and in responsiveness act to defend against protein-calorie malnutrition? What, then, is the evidence for the proposed hypothesis that these alterations are not abnormalities, but rather appropriate responses?

The selective chronic elevation of the diabetogenic activity of growth hormone and of the glucocorticoids, plus the more transient elevations of glucagon and probably the catecholamines, act to spare glucose and stimulate gluconeogenesis, especially when elevated in combination with one another (12). Glucose utilization is inhibited in those tissues not having an absolute requirement for it as an energy source. The lowered insulin to glucagon ratio also acts to spare glucose (50). Additionally, free fatty acids and ketone bodies are made more readily available as fuels for those tissues which can utilize them. The selective decrease in somatomedin, the anabolically active agent of growth hormone, and the decrease of insulin and thyroid hormone act to limit glucose utilization by those tissues not possessing an absolute requirement for it, act to decrease energy and oxygen utilization in general, and finally, more importantly, act to spare glucose and gluconeogenic amino acids by reducing growth, a process which would consume these fuels wastefully when life itself may be in the balance.

The endocrine changes with malnutrition are many and varied. In the child, growth ceases through mechanisms which, at least in part, are mediated through alterations in the endocrine system. Other endocrine changes appear to alter body metabolism so as to conserve that little substrate available for life maintenance functions. Death from malnutrition occurs when this adaptation is no longer possible or when a supervening stress, such as infection, develops and the already stressed organism is unable to mount the appropriate additional response needed to survive. Therefore, many of the so-called endocrine abnormalities of malnutrition might be better considered as important, protective adaptations to the deficiencies or imbalances in energy and protein. I feel they are particularly excellent examples of the ability of the young to adjust to an environment which is not always hospitable or supporting.

\section{REFERENCES AND NOTES}

1. Aguilar-Parada. E., Eisentraut, A. M., and Unger, R. H.: Effects of starvation on plasma pancreatic glucagon in normal man. Diabetes, 18: 717 (1969).

2. Baig, H., and Edozien, J. A.: Carbohydrate metabolism in kwashiorkor, Lancet. 2: 662 (1965)

3. Becker, D. J., Pimstone, B. L., and Hansen, J. D. L.: The relation between insulin secretion, glucose tolerance, growth hormone, and serum proteins in proteincalorie malnutrition. Pediatr. Res., 9: 35 (1975).

4. Becker, D. J., Pimstone, B. L., Hansen, J. D. L., and Hendricks, S.: Insulin secretion in protein-calorie malnutrition. I. Quantitative abnormalities and response to treatment. Diabetes, 20: 542 (1971).

5. Becker, D. J., Pimstone, B. L., Hansen, J. D. L., and Hendricks, S.: Serum albumin and growth hormone relationships in kwashiorkor and the nephrotic syndrome. J. Lab. Clin. Med., 78: 865 (1971).

6. Becker, D. J., Pimstone, B. L., Hansen, J. D. L., MacHutchon, B., and Drysdale, A.: Patterns of insulin response to glucose in protein-calorie malnutrition. Am. J. Clin. Nutr., 25: 499 (1972).

7. Bermudez, F., Surks, M. I., and Oppenheimer, J. H.: High incidence of decreased serum triiodothyronine concentration in patients with nonthyroidal disease. J. Clin. Endocrinol. Metab., 41: 27 (1975).

8. Chopra, I. J., Chopra, U., Smith, S. R., Reza, M., and Solomon, D. H.: Reciprocal changes in serum concentrations of $3,3^{\prime} 5^{\prime}$-triiodothyronine (reverse $T_{3}$ ) and 3,3',5-triiodothyronine $\left(\mathrm{T}_{3}\right)$ systemic illness. J. Clin. Endocrinol. Metab., 41: 1043 (1975).

9. Chopra, I. J.. and Smith, S. R.: Circulating thyroid hormones and thyrotropin in adult patients with protein-calorie malnutrition. J. Clin. Endocrinol. Metab., 40: 221 (1975).

10. Croxson, M. S., Hall, T. D., Kletzky, O. A., Jaramillo, J. E., and Nicoloff, J. T.: Decreased serum thyrotropin induced by fasting. J. Clin. Endocrinol. Metab., 45: 560 (1977).

11. Dillmann, W. H., and Oppenheimer, J. H.: Glucagon influences the expression of thyroid hormone action: Discrepancy between nuclear triiodothyronine receptor number and enzyme responses. Endocrinology, 105: 74 (1979).

12. Eigler, N., Sacca, L., and Sherwin, R. S.: Synergistic interactions of physiologic increments of glucagon, epinephrine, and cortisol in the dog. J. Clin. Invest. 63: 114 (1979).

13. Einsenstein, A., Hagg, S., Vagenakis, A., Fang, S., Ransil, B., Braverman, L., and Ingbar, S.: Observations on the peripheral metabolism of 3,3,5'-triiodothyronine (reverse $\mathrm{T}_{3}, \mathrm{rT}_{3}$ ) in fed and fasted patients. Clin. Res., 25: 294A (1977).

14. Graham, G. G., Cordano, A., Blizzard, R. M., and Cheek, D. B.: Infantile malnutrition: Changes in body composition during rehabilitation. Pediatr. Res., 3: 579 (1969).

15. Grant, D. B., Hambley, J., Becker, D., and Pimstone, B. L.: Reduced serum sulphation factor activity in patients with protein-calorie malnutrition. Arch. Dis. Child., 48: 596 (1973).

16. Hadden, D. R.: Glucose, free fatty acid, and insulin interrelations in kwashiorkor and marasmus. Lancet, 2: 589 (1967).

17. Hales, C. N., and Randle, P. J.: Effects of low-carbohydrate diet and diabetes mellitus on plasma concentrations of glucose, non-esterified fatty acids, and mellitus on plasma concentrations of glucose, non-esterified fatty
insulin during oral glucose tolerance tests. Lancet, $1: 790$ (1963).

18. Hopkins, L. L.. Ransome-Kuti, O., and Majaj. A. S.: Improvement of impaired carbohydrate metabolism by chromium (III) in malnourished infants. Am. J. Clin. Nutr., 21: 203 (1968)

19. Ingenbleek, Y., and Beckers, C.: Triiodothyronine and thyroid-stimulating hormone in protein-calorie malnutrition in infants. Lancet, 2: 845 (1975).

20. Ingenbleek, Y.. De Nayer, P., and De Visscher, M.: Thyroxine-binding globulin in infant protein-calorie malnutrition. J. Clin. Endocrinol. Metab., 39: 178 (1974).

21. James, W. P. T., and Coore, H. G.: Persistent impairment of insulin secretion and glucose tolerance after malnutrition. Am. J. Clin. Nutr., 23: 386 (1970).

22. Jayarao, K. S., and Raghuramulu, N.: Growth hormone and insulin secretion in protein-calorie malnutrition, as seen in India. In: L. I. Gardner, P. Amacher: Endocrine Aspects of Malnutrition. pp. 91-98 (The Kroc Foundation, Santa Ynez, CA, 1973).

23. Marliss, E. B., Aoiki, T. T., Unger, R. H., Soeldner, J. T., and Cahill, G. F., Jr.: Glucagon levels and metabolic effects in fasting man. J. Clin. Invest., 49: 2256 (1970).

24. Merimee, T. J., and Fineberg, E. S.: Starvation-induced alterations of circulating thyroid hormone concentrations in man. Metabolism, 25: 79 (1976).

25. Milner. R. D. G.: Insulin secretion in human protein-calorie malnutrition. Proc. Nutr. Soc., 31: 219 (1972).

26. Monckeberg, F., Donoso, G., Oxman, S., Pak, N., and Meneghello, J.: Human growth hormone in infant malnutrition. Pediatrics, 31: 58 (1963).

27. Muller, W. A., Aoki, T. T., and Cahill, G. F., Jr.: Effect of alanine and glycine on glucagon secretion in postabsorptive and fasting obese man. J. Clin. Endocrinol. Metab., 40: 418 (1975).

28. Pain, R. W., and Phillips, P. J.: Thyroid-hormone levels in protein-calorie malnutrition. Lancet, I: 202 (1976).

29. Parra, A., Personal communication.

30. Parra, A., Garza, C., Garza, Y., Saravia, J. L., Hazelwood, C. F., and Nichols, B. L.: Changes in growth hormone, insulin and thyroxine values and in energy metabolism of marasmic infants. J. Pediatr., 82: 133 (1973).

31. Parra, A., Garza, C., Klish, W., Garcia, G., Argote, R. M., Canesco, L., Cuellar, A., and Nichols, B. L.: Insulin-growth hormone adaptations in marasmus and kwashiorkor as seen in Mexico. In: L. I. Gardner, P. Amacher: Endocrine 
Aspects of Malnutrition. pp. 31-43 (The Kroc Foundation, Santa Ynez, CA 1973).

32. Parra, A., Klish, W., Cuellar, A., Serrano, P. A., Garcia, G., Argote, R. M., Canseco, L., and Nichols, B. L.: Energy metabolism and hormonal profile in children with edematous protein-calorie malnutrition. J. Pediatr., 87: 307 (1975).

33. Pimstone, B. L., Barbezat, G., Hansen, J. D. L., and Murray, P.: Growth hormone and protein-calorie malnutrition. Impaired suppression during induced hyperglycemia. Lancet, 2: 1333 (1967)

34. Pimstone, B. L., Barbezat, G., Hansen, J. D. L., and Murray, P.: Studies on growth hormone secretion in protein-calorie malnutrition. Am. J. Clin. Nutr. 21: 482 (1968)

35. Pimstone, B. L., Becker, D. J., and Hansen, J. D. L.: Human growth hormone in protein-calorie malnutrition. In: A. Pecile, E. E. Muller: pp. 389-401 (Excerpta Medica Foundation, Amsterdam, 1972).

36. Pimstone, B. L., Becker, D. J., and Hansen, J. D. L.: Human growth and hormone and sulphation factor in protein-calorie malnutrition. In: L. I. Gardner, P. Amacher: Endocrine Aspects of Malnutrition. pp. 73-90 (The Kroc Foundation, Santa Ynez, CA, 1973)

37. Pimstone, B., Becker, D., and Hendricks, S.: TSH response to synthetic thyrotropin-releasing hormone in human protein-caloric malnutrition. J. Clin. Endocrinol. Metab., 36: 779 (1973).

38. Pimstone, B. L., Becker, D., Kronheim, S.: Disappearance of plasma growth hormone in acromegaly and protein-calorie malnutrition after somatostatin. $\mathbf{J}$. Clin. Endocrinol. Metab., 40: 168 (1975).

39. Pimstone, B. L., Becker, D., Weinkove, C., and Mann, M.: Insulin secretion in protein-calorie malnutrition. In: L. I. Gardner, P. Amacher: Endocrine Aspects of Malnutrition. pp. 289-305 (The Kroc Foundation, Santa Ynez, CA, 1973).

40. Pimstone, B. L., Wittman. W., Hansen, J. D. L., and Murray, P.: Growth hormone and kwashiorkor. Role of protein in growth hormone homeostasis. Lancet, 2: 779 (1966)

41. Portnay, G. I., O'Brian, J. T., Bush, J., Vagenakis, A. G., Azizi, F., Arky, R. A., Ingbar, S. H., and Braverman, L. E.: The effect of starvation on the concentration and binding of thyroxine and triiodothyronine in serum and on the response to TRH. J. Clin. Endocrinol. Metab., 39: 191 (1974).

42. Raghuramulu, N., and Rao, K. S. J.: Growth hormone secretion in proteincalorie malnutrition. J. Clin. Endocrinol. Metab., 38: 176 (1974).

43. Robinson, H., Cocks, T., Kerr, D., and Picou, D.: Fasting and postprandial levels of plasma insulin and growth hormone in malnourished Jamaican children

Copyright (ㄷ 1980 International Pediatric Research Foundation, Inc. 003 -3998/80/1412-1299\$02.00/0 during catch-up growth and after complete recovery. In: L. I. Gardner, P. Amacher: Endocrine Aspects of Malnutrition. pp. 45-72 (The Kroc Foundation, Santa Ynez, CA, 1973).

44. Samuel, A. M., Kadival, G. V., Patel, B. D., and Desai, A. G.: Adrenocorticoids and corticosteroid binding globulins in protein calorie malnutrition. Am. J. Clin. Nutr., 29: 889 (1976).

45. Schussler, G. C., and Orlando, J.: Fasting decreases trioodothyronine receptor capacity. Science (Wash. D. C.), 199: 686 (1978)

46. Sloane, D., Taitz, L. S., and Gilchrist, G. S.: Aspects of carbohydrate metabolism in kwashiorkor. With special reference to spontaneous hypoglycemia. Br. Med. J., $1: 32$ (1961).

47. Smith, S. R., Bledsoe, T., and Chhetri, M. K.: Cortisol metabolism and the pituitary-adrenal axis in adults with protein-calorie malnutrition. J. Clin. Endocrinol. Metab., 40: 43 (1975).

48. Smith, S. R. Edgar, P. J., Pozefsky, T., Chhetri, M. K., and Prout, T. E. Growth hormone in adults with protein-calorie malnutrition. J. Clin. Endocrinol. Metab., 39: 53 (1974).

49. Spaulding, S. W., Chopra, I. J., Sherwin, R. S., and Lyall, S. S.: Effect of caloric restriction and dietary composition on serum $T_{3}$ and reverse $T_{3}$ in man. J. Clin. Endocrinol. Metab., 42: 197 (1976).

50. Unger, R. H.: Glucagon and the insulin: glucagon ratio in diabetes and other catabolic illnesses. Diabetes, 20: 834 (1971).

51. Unger, R. H., Eisentraut, A. M., and Madison, L. L.: The effects of total starvation upon the levels of circulating glucagon and insulin in man. J. Clin. Invest., 42: 1031 (1963).

52. Vagenakis, A. G., Burger, A., Portnay, G. I., Rudolph, M., O'Brian, J. T., Azizi, F., Arky, R. A., Nicod, P., Ingbar, S. H., and Braverman, L. E.: Diversion of peripheral thyroxine metabolism from activating to inactivating pathways during complete fasting. J. Clin. Endocrinol. Metab., 41: 191 (1975).

53. Van Wyk, J.: (personal communication)

54. Vinik, A. I., Kalk, W. H., McLaren, H., Hendricks, S., and Pimstone, B. L.: Fasting blunts the TSH response to synthetic thyrotropin-releasing hormone (TRH). J. Clin. Endocrinol. Metab., 40: 509 (1975).

55. Presidential Address presented before the Society for Pediatric Research, May 3, 1979, Atlanta, GA.

56. Requests for reprints should be addressed to: Jo Anne Brasel, M.D., General Clinical Research Center, Harbor-UCLA Medical Center, 1000 West Carson Street, Torrance, CA 90509 (USA).

Printed in U.S.A. 